
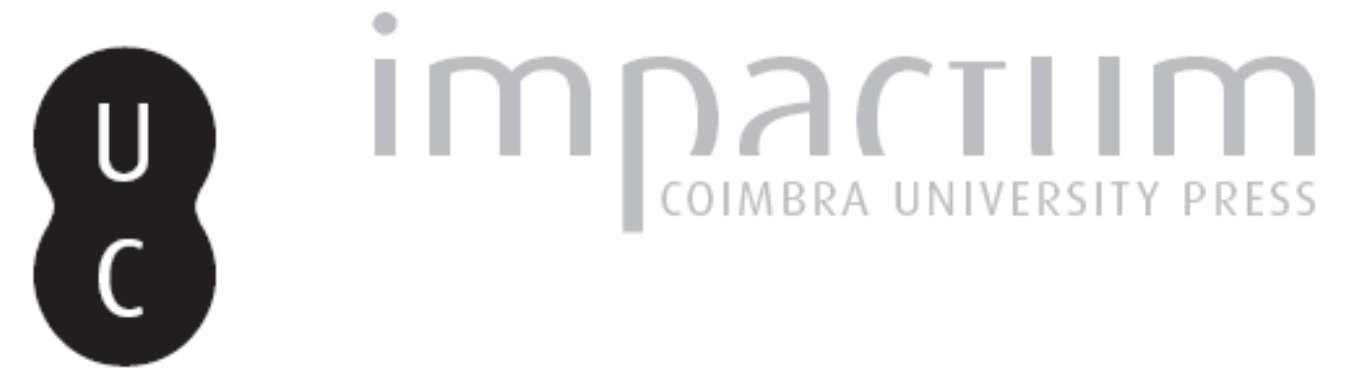

\title{
O fator religioso nos conflitos
}

\section{Autor(es): $\quad$ Pires, Nuno Lemos}

Publicado por: Imprensa da Universidade de Coimbra

URL persistente:

URI:http://hdl.handle.net/10316.2/43833

DOI:

DOI:https://doi.org/10.14195/2183-8925_36_13

Accessed : $\quad$ 26-Apr-2023 08:17:45

A navegação consulta e descarregamento dos títulos inseridos nas Bibliotecas Digitais UC Digitalis, UC Pombalina e UC Impactum, pressupõem a aceitação plena e sem reservas dos Termos e Condições de Uso destas Bibliotecas Digitais, disponíveis em https://digitalis.uc.pt/pt-pt/termos.

Conforme exposto nos referidos Termos e Condições de Uso, o descarregamento de títulos de acesso restrito requer uma licença válida de autorização devendo o utilizador aceder ao(s) documento(s) a partir de um endereço de IP da instituição detentora da supramencionada licença.

Ao utilizador é apenas permitido o descarregamento para uso pessoal, pelo que o emprego do(s) título(s) descarregado(s) para outro fim, designadamente comercial, carece de autorização do respetivo autor ou editor da obra.

Na medida em que todas as obras da UC Digitalis se encontram protegidas pelo Código do Direito de Autor e Direitos Conexos e demais legislação aplicável, toda a cópia, parcial ou total, deste documento, nos casos em que é legalmente admitida, deverá conter ou fazer-se acompanhar por este aviso.

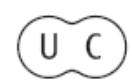



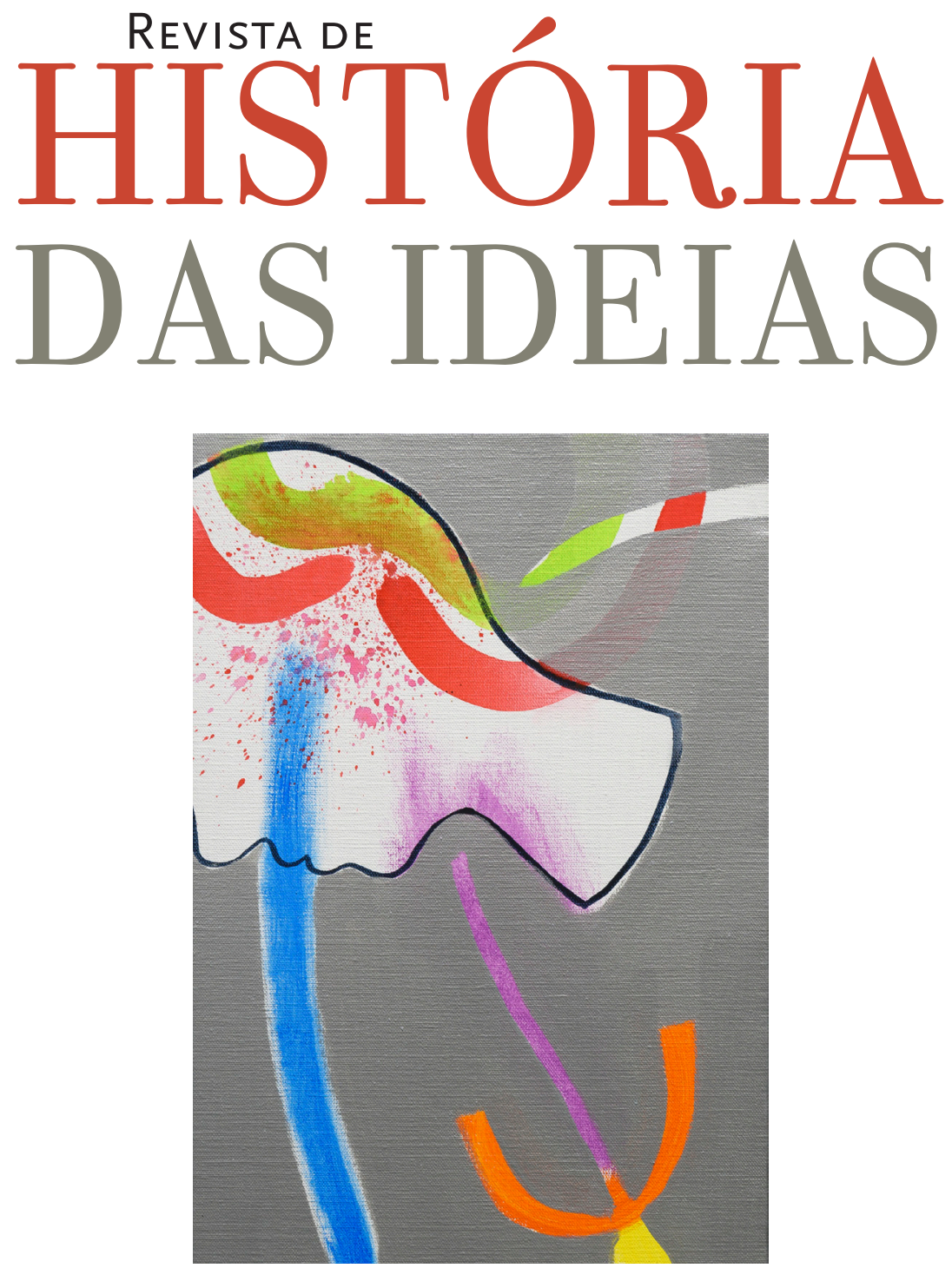

Religiões e Culturas

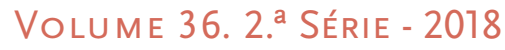




\title{
O FATOR RELIGIOSO NOS CONFLITOS THE RELIGIOUS FACTOR IN CONFLICTS
}

\author{
NUNO LEMOS PIRES \\ nlemospires@gmail.com \\ Academia Militar \\ CEI IUL-ISCTE \\ ORCID: 0000-0002-1731-3930
}

Texto recebido em / Text submitted on: 30/09/2017

Texto aprovado em / Text approved on: 09/11/2017

\section{Resumo:}

O religioso sempre foi e é um fator explorado, manipulado, exacerbado, mal interpretado, mas, muitas das vezes, central nas causas e explicações de muita da conflitualidade e das guerras, passadas, atuais e futuras. Neste texto, procuraremos enquadrar a importância deste fator na história, de acordo com a circunstância geopolítica, na forma como se entende, diferencia e aplica, tanto na sociedade como nas escolhas políticas de cada Estado. Por último, tentaremos analisar a importância do papel das instituições públicas, e em especial dos exércitos, na gestão da violência e na garantia da paz.

\section{Palavras-chave:}

Religião, Política, Violência, Exércitos, Paz. 


\begin{abstract}
:
Religions have always been, and still are, an exploited, manipulated, exacerbated and wrongly interpreted factor. Nonetheless, they are, most of the times, central to understanding the causes and explanations of many of the past, ongoing and future wars and conflicts. I will try to frame the importance of this factor in history, in accordance with each geopolitical circumstance, and inasmuch as it is understood, is differentiated and is applied both in society as in the political choices of every state. Finally, I will try to analyze the importance of the public institutions, in particular the Armed Forces, in managing violence and ensuring peace.
\end{abstract}

\title{
Keywords:
}

Religion, Politics, Violence, Armies, Peace.

\section{Introdução}

A religião não é um fator secundário. O religioso sempre foi e é um fator explorado, manipulado, exacerbado, mal interpretado, mas, muitas das vezes, central nas causas e explicações de muita da conflitualidade e das guerras, passadas, atuais e futuras. Por forma a mantermos este texto suficientemente breve, vamos fazer uma abordagem do tema subdividida em quatro grandes capítulos ${ }^{(1)}$.

Em primeiro lugar, centrar-nos-emos apenas em partes selecionadas da evolução histórica, da dimensão do fator religioso no contexto da diversidade em que nos encontramos, naquilo que nos divide e que nos une, nas guerras, nos conflitos e na obtenção e gestão do poder.

Em segundo lugar, tentaremos fazer uma análise um pouco mais circunscrita às três «religiões do Livro» - Judaísmo, Cristianismo e Islão - e procuraremos entender como essa dimensão foi e é fundamental, mas

(1) Este texto constitui uma versão revista de uma conferência do autor sobre «As religiões, a guerra e a paz: Atualidade de um tema», proferida no seminário «Pela Paz e futuro da Humanidade», organizado pelo Ordinarato Castrense (http:/ / ordinariato. castrense.pt/seminario-paz-e-futuro-da-humanidade/ ). 
não única, para cimentar e harmonizar projetos políticos de construção de nações e de alianças.

Em terceiro lugar, vamos esboçar uma breve panorâmica sobre guerra e paz, incluindo o terrorismo transnacional de inspiração religiosa, para entendermos melhor a relação entre as várias dimensões precedentes.

Por último, procuraremos analisar a importância do papel das instituições públicas, e em especial dos exércitos, na gestão da violência e na garantia da paz. A dimensão religiosa pode ser um fator relevante na narrativa da justificação da violência e na fundamentação para a obtenção de objetivos políticos, mas as instituições que secularmente gerem a violência e garantem a paz são um contraponto importante para a contenção do fenómeno.

\section{Do que divide e une o religioso}

Estamos divididos pela história e pela geografia. Podemos viver em terrenos férteis com recursos abundantes ou em zonas áridas onde nada cresce e a água rareia, em territórios escassamente povoados ou sobrepovoados, ou mesmo em áreas do planeta onde as alterações climáticas mais se fazem sentir e a vida se tornou insustentável. Podemos pertencer a Estados coesos, democráticos e desenvolvidos, ou nascer em Estados fragilizados, sob regimes ditatoriais ou subdesenvolvidos. Podemos viver em países rodeados de aliados, isolados em ilhas afastadas de tudo e todos, ou sob permanentes ameaças de inimigos. Tanto podemos habitar em regiões tradicionalmente pacíficas como em áreas onde, conjunturalmente ou mais frequentemente ao longo da história, se verificaram disputas, conflitos e guerras.

Uns terão a sorte de viver em países onde todos estudam e a maioria consegue atingir os mais elevados níveis de escolaridade, onde o ambiente é aberto, tolerante e inclusivo, e outros poderão crescer sem escola, sem liberdade de expressão, sem sequer sentir o reconhecimento das mais elementares garantias expressas na Declaração Universal dos Direitos Humanos $^{(2)}$. Vivemos em pequenos grupos ou famílias. Podemos, por isso, estar divididos, tanto pelas opções que tomámos como pelas que

(2) http:/ / www.gddc.pt/ direitos-humanos/textos-internacionais-dh/tidhuniversais / cidh-dudh.html (consultado em 18 de setembro de 2017). 
não fizemos, ou mesmo por aquelas que nos impõem. Separam-nos as ideias que defendemos, as escolhas que fazemos, o exercício de uma profissão ou de uma forma de viver, os hábitos que assumimos, a restrição ou não à liberdade de expressão, de pensamento, de cultura e de bem-estar económico na comunidade onde habitamos.

Escolhemos e vivemos livremente, ou são-nos impostas ideologias, crenças, filosofias e religiões. Há sistemas políticos laicos, há os inspirados em religiões, e há ainda os que têm um pouco dessas duas dimensões. Há pessoas que têm, há os que não têm e há também os que não sabem se têm algum tipo de crença $^{(3)}$ em ideologias e/ou religiões. Vamos, pela natureza do tema geral deste texto, aprofundar o que nos divide e o que nos une nas religiões.

A união é um ato de consciência, desejavelmente voluntário, assumido ou herdado. Constrói-se, edifica-se e dá muito trabalho para a sua manutenção. As grandes uniões entre povos traduzem-se em alianças. Umas mais permanentes, outras meramente conjunturais. Os países, em si mesmos, são o produto da união entre os que pertencem a uma determinada área geográfica, que podem ser todos de uma só ou de várias nações, que podem estar num único território ou separados por mares interiores e exteriores. O que une os cidadãos sob uma mesma bandeira pode ser, ou não, entre diversas variáveis, a língua, a história comum, a religião, ou, em contraponto, a existência de um inimigo comum, a busca de um projeto, ou ainda a submissão a uma entidade mais poderosa.

As pessoas podem viver sozinhas ou buscar a união como famílias que, por sua vez, pertencem a comunidades maiores, sejam estas simples clãs, tribos, aldeias ou povoados. Podem unir-se por género, por etnia, por nível de riqueza ou, simplesmente, pelo respeito mútuo sem qualquer distinção de base. Podem-se unir por partilhar ideias comuns, ideologias próximas ou por professarem religiões que lhes dão uma determinada identidade coletiva(4).

As religiões podem ser um fator de união, mas também podem ser instrumentalizadas como forma de aprofundar e de justificar contendas, confrontos, conflitos e guerras. A religião une conceitos complementares.

(3) Crente, a partir do princípio do grande pensador Descartes: «Sou um ser finito capaz de pensar o infinito»» (Neves 2012: 16).

(4) «O socialismo era ofensivo na sua afirmação de que 'um trabalhador não tem país' - de que o proletariado em todos os países constitui uma classe cujo significado político supera o de nação [...]. A al-Qaeda repudia a noção de Estados-Nação separados e trabalha para a reunificação de um império islâmico que domine o mundo» (Owen 2016: 77 e 118). 
De um Ser Humano, imperfeito e capaz de usar a violência com um ou vários deuses, com uma noção superior de «Bem» que deve traduzir a razão(5), a tranquilidade, a segurança, a justiça e a paz. De uma noção divina de paz e de concórdia entre os seres humanos, mas também de determinadas narrativas assentes numa entidade vingadora e interventiva junto dos seres humanos, nas causas dos seus conflitos, que agrava, extrema e provoca a irracionalização das guerras.

\section{Das religiões e das Três Religiões do Livro}

Das religiões, com ou sem deuses ou Deus, nas ramificações, no entendimento e na teologia ${ }^{(6)}$. O mundo tem inúmeras religiões e seitas, profundamente variadas, a que não são estranhos os contextos de origem, as características do território, a geografia, a história, a cultura dos povos, as dinâmicas políticas da época, o tipo de literatura, as tradições que num primeiro momento absorvem para, posteriormente, transformar e (re) edificar, gerando uma identidade comunitária - um povo. Não nascemos livres na religião, como em outras tantas dimensões ideológicas, porque o berço marca, quase sempre, uma primeira escolha, que, consoante a circunstância, pode ser mais livre ou mais direcionada. Quase todas as religiões incluem atos de iniciação, que à nascença os familiares assumem, ou simplesmente preferem não assumir. Um batismo, uma apresentação na igreja, na mesquita, na sinagoga, perante os deuses de um templo ou pedindo a bênção a um «homem santo», as formas são muitas e a simples recusa de qualquer destes atos também significa uma ação em si mesma.

Um deus. Vários deuses. A Natureza que reflete o divino. Animismos, xamanismos, seres extraterrestres que nos vigiam ou noções difíceis de «Bem» e de «Mal» que nos regem (profundamente subjetivas e a que nos iremos referir mais adiante). Da busca hinduísta pela «verdade», ou dos budistas com as suas «quatro nobres verdades» ${ }^{(7)}$. O que nos divide, à

(5) «Tudo quanto, na ordem humana, vai contra a razão, é vicioso», São Tomás de Aquino (ST II-II 168,4 em Neves 2006: 34).

(6) «A distinção feita pelo teólogo Hans Küng entre religiões "proféticas", "místicas" e "sapienciais", sendo estas últimas cultivadas na China por doutrinas como a Confucionista» (Correia 2012: 83).

(7) «Verdade para Ghandi, foi o objetivo da sua alma, é a palavra para designar o que ele entende por Ser Supremo para quem, cada pensamento, palavra, e ação se devem 
nascença e enquanto crescemos, deve ser encarado como um «Sumo Bem, que é possível no mundo, a saber, a moralidade, na medida em que apenas é possível pela liberdade» (Kant 1795: 47). A diversidade é uma das maiores riquezas da humanidade.

Em si mesmas, as religiões não dividem mas, na sua aplicação e entendimento, na forma como são usadas para argumentar em favor de determinados objetivos políticos, podem ser causa de conflitos e guerras. "A tutela religiosa, além de ser mais prejudicial, é também a mais desonrosa de todas» (Kant 1795: 17). As religiões unem mais do que separam, mas, na ação e na aplicação, podem causar o efeito contrário ${ }^{(8)}$ se não conferirmos, não defendermos, não garantirmos a todos a liberdade de credo, de culto, de ter ou não ter religião, de não confundir religiões com sistemas de crenças, ou com a prática de determinadas instituições.

No Judaísmo, no Cristianismo e no Islão dividem-se as interpretações e a forma de viver a religião, fundamentalmente na prática, porque, devendo ser do foro exclusivamente íntimo, dependem da forma assumida por cada um. São três grandes religiões que, por sua vez, se dividem em grupos e interpretações muitíssimo variadas e diferentes. Mesmo que a origem seja comum, que todos descendam de Abraão e que a Torá judaica seja uma referência comum para todos, as variações são imensas. Há ortodoxos, sefarditas, coptas, católicos, anglicanos, protestantes, luteranos, batistas, evangélicos, calvinistas, sunitas, xiitas, sufistas e para cima de duzentas divisões, conforme a religião base, a geografia, a história, a interpretação ou mesmo a influência de outras religiões.

Mas o mais marcante, como afirmámos, é a forma como cada religião é vivida e como encara as restantes. Há religiões que, na sua prática, são prescritivas na sua natureza, definindo formas de vestir, de comunicar, de rezar, de comer, os dias de trabalho e de descanso, as maneiras possíveis de casamento e as condições de acesso à pertença ${ }^{(9)}$. Na prática humana, isto não é, de todo, exclusivamente do foro do religioso, antes

encaminhar. [...] As quatro nobres verdades: toda a existência é sofrimento, todo o sofrimento é causa da ignorância e do apego, pode vencer-se o sofrimento superando a ignorância e o apego e esta superação alcança-se através do Nobre Caminho Óctuplo [...] a palavra reta, a ação reta e a vida reta» (Neves 2012: 31, 60, 70 e 71).

(8) «É muito frequente as pessoas confundirem religião com superstição, espiritualidade, crença em forças sobrenaturais ou fé em deuses» (Harari 2017: 203).

(9) «Um fator dominante na vasta e muitas vezes aterradora arena em que a política e a religião se intercetam» (Hazleton 2015: 24). 
resulta de tradições culturais, costumes locais e transversais. Há religiões que podem ser entendidas como a base de sistemas políticos completos e definidores, inclusivamente das leis principais de alguns Estados, e que podem ser um dos fatores para «uma disputa sobre a melhor forma de ordenar a sociedade» (Owen 2016: 23). No extremo oposto, há formas de encarar a religião, simplesmente, como um caminho que cada um percorre na sua intimidade, participando, praticando e regendo-se ou não por ele, mas sempre de sua livre vontade, nos atos públicos que a sua religião organiza e permite ${ }^{(10)}$.

As chamadas «Três Religiões do Livro» (isto é, as religiões abraâmicas) compreendem um sistema de crenças que pretendem envolver todos os âmbitos da existência da pessoa e da comunidade, com normas e ritos que espelham uma mundividência, uma antropologia e um itinerário de crescimento que configura uma espiritualidade pessoal ${ }^{(11)}$. São religiões, na realidade, muito distintas entre e dentro de cada uma delas (Devji 2016), e algumas, na sua prática, têm um determinado potencial de desequilíbrio e também de fundamentalismo. A isto não são estranhas as diferentes lideranças comunitárias (podendo ser manipuladas e/ou manipuladoras), como o poderá ser uma hipervalorização da dimensão metafísica (o divino), esquecendo o ser humano e a natureza ${ }^{(12)}$, ou seja, subjugando com isso a racionalidade ${ }^{(13)}$.

O que mais deve unir, entre as várias religiões, mesmo quando não se trate rigorosamente de religiões (como será o caso do Budismo ou do Confucionismo, que muitos consideram antes como uma filosofia ou uma prática) ${ }^{(14)}$, é a noção de «bem». Que há um «bem» a prosseguir, a alcançar e que, mesmo os que não professam qualquer religião, pos-

(10) «Os deuses e, a seu tempo, um só Deus, são uma maneira de transcender os interesses erráticos dos seres humanos e de procurar uma autoridade desinteressada que possa ser imparcial, e em que se possa ter confiança e respeito» (Damásio, 2017: 243).

(11) «A religião é um contrato, ao passo que a espiritualidade é uma viagem» (Harari 2017: 207).

(12) «Outras religiões, especialmente o Jainismo, o Budismo e o Hinduísmo, demonstram ainda mais empatia pelos animais» (Harari 2017: 112).

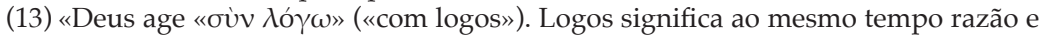
palavra, uma razão que é criadora e capaz precisamente de se comunicar mas como razão (Bento XVI 2006: 3).

(14) «Não há politeísmos no Budismo e que o Budismo não é propriamente uma religião mas, no confronto com o Cristianismo, o conceito de religião alternativa é um dado sociológico com a realidade religiosa identitária. [...] O Confucionismo como filosofia de vida e uma teologia sapiencial» (Neves 2012: 126). 
sam sentir que uma causa que procura o «bem» não o constrange, não o limita e é compatível com a sua própria liberdade de (não) escolher. Às três religiões do livro, une-as um mesmo conceito de monoteísmo; une-as as mesmas leituras (os textos considerados sagrados) ${ }^{(15)}$; une-as os mesmos profetas.

Divide-as, no entanto, o tempo e os textos seguintes, as interpretações e as suas subdivisões. Para se entender o Alcorão, é importante compreender a Torá e a Bíblia, e sem o Antigo Testamento também não há a Bíblia cristã. Mas, se a palavra une, a mesma também pode separar. Um judeu pode não sentir necessidade de ler o Novo Testamento e um cristão pode não ter a curiosidade de ler o Alcorão. Por sua vez, o Alcorão também invoca textos da Bíblia e os profetas comuns ao Judaísmo e ao Cristianismo. Mas, porque é posterior no tempo, também conduz a interpretações de superioridade sobre as anteriores. A Bíblia é, no entendimento dos cristãos, uma evolução e um avanço: «Não penseis que vim revogar a Lei ou os Profetas. Não vim revogá-los, mas levá-los à perfeição» (Mt 5: 17); e o Alcorão, para os muçulmanos, é o último passo na perfeição da religião abraâmica: «a religião verdadeira para que reluza sobre qualquer outra religião» (Alc. 48: 281). Assim o defendem os respetivos fiéis de cada uma destas religiões. Daí a desunião, daí o desconforto e o conflito de ideias quando uns reclamam ter melhores teologias e teosofias do que os outros.

\section{Da religião e da política}

$\mathrm{Na}$ antiguidade egípcia, grega, cartaginesa ou romana os conceitos de soberania, de nação, de república ou de reino, ainda tão longe dos conceitos dos Estados pós Vestefália (1648), não careciam de uma reflexão muito profunda sobre o papel das religiões e da política, porque estas, simplesmente, não nasciam separadas. Não existiam desligadas no dia-a-dia, na invocação dos deuses para a vida quotidiana, na caracterização dos soberanos como divinos, ou mesmo nas separações dos poderes, como era visível no caso romano. A questão vai-se colocar, naturalmente,

(15) «A relação entre as como se dizia três "Leis"ou três "ordens de vida": Antigo Testamento, Novo Testamento, Alcorão» (Bento XVI 2006: 2). 
quando se tentou separar completamente os conceitos de Estado e de Religião, a partir do século XVII, em especial na Europa.

Judaísmo, Cristianismo, Islão, Confucionismo. São ações sociais motivadas por princípios religiosos mas são também, em medidas e dimensões muito variáveis, projetos de sistemas e inspirações políticas. Por exemplo, Abraão foi influenciado pelo código instituído pelo rei caldeu Hammurabi, rei da Babilónia. O código de Hammurabi não tinha nenhum fundamento religioso (apesar de ser referido o Deus caldeu Marduk), sendo uma lei geral, necessária à sobrevivência em sociedade. Os judeus deram um fundamento religioso a esses preceitos morais (no Génesis, Êxodo e Deuteronómio), acrescentando normas alimentares que assumiram um aspeto religioso (Levítico). Na evolução das doze tribos de Israel, escreveram-se leis e regras sociais que regularam e afirmaram princípios de vida em sociedade, de regulação jurídica e de ordenação política. Sem a jurisprudência construída a partir da vida de Abraão, de Moisés mas, acima de tudo, de David e de Salomão, não entenderíamos a ordem social ainda vigente. Na cristianização do Império Romano ficou assim clarificado que se respeitava o princípio da separação, segundo o qual se deve dar «a César o que é de César» e «a Deus o que é de Deus» (Mt 22,15-21), mas foi também através de evocações religiosas que se aprofundaram algumas das suas dimensões políticas, como sucedeu com o imperador Constantino, que deve, em parte, o seu reconhecimento público à assunção do Cristianismo como religião do Império (Flanery 2016: 34).

Nas filosofias, e também na religião, confucionistas, budistas e hindus valoraram formas de relacionamento social e político que estão bem presentes em extensas regiões do planeta, profundamente habitadas, que aprenderam a viver em sociedade com regras muito distintas dos conceitos gregos e romanos. Mas foi na definição dos Estados saídos de Vestefália (1648) que se criaram alguns dos conceitos estruturantes, os maioritariamente aceites na atual ordem europeia e ocidental, e que mais ruturas causaram à data do seu aparecimento.

No início do século XVII, e devido a uma guerra que se apresentou na sua principal motivação assente em diferenças religiosas, afrontaram-se múltiplas divisões. O que nasceu da oposição entre protestantes (luteranos e calvinistas), entre católicos e protestantes, entre soberanos que escolhiam a sua religião de Estado e entre os vários soberanos que escolheram este ou aquele aliado, gerou uma nova forma de organizar a sociedade. Em virtude da guerra, mas fundamentalmente em resultado da paz alcançada em 1648 
(e posteriormente, já no século XVIII, devido à influência de Montesquieu na construção de um sistema político liberal baseado na legitimidade democrática, no princípio da legalidade e na separação de poderes) criaram-se modernos conceitos de Estado, que apelidamos de «ocidentais».

No século XIX, a questão política que parecia opor protestantes a católicos transcendeu-se e conduziu a uma outra discussão, entre um sistema constitucional ou absolutista, liberal, comunista ou anarquista. A questão da divisão religiosa deixou de ser um tópico divisionista. Separou-se, em menor ou maior grau, a Religião da Política e a discussão passou a ser, quase exclusivamente, sobre modelos políticos que podiam, inclusivamente, defender a expulsão da religião do âmbito social (como aconteceu em alguns modelos comunistas e anarquistas) $)^{(16)}$.

Parecia, pelo menos para os povos europeus e ocidentais, que o secularismo ${ }^{(17)}$ se tinha imposto e que seria universal. Mas não era, nem é, um modelo universal. Hoje persistem inúmeros exemplos de modelos, mais ou menos híbridos, que juntam em determinada medida o lado confessional dentro da política, mesmo no denominado sistema ocidental. Afinal, a rainha do Reino Unido é também a chefe da Igreja Anglicana; e, em Israel, as leis da República, comumente aceites como liberais e democráticas, têm de ter a aprovação do rabinato ${ }^{(18)} \ldots$

A seguir à desagregação do Império Otomano, no final da Primeira Guerra Mundial (1914-1918), onde o Estado controlava o clero ${ }^{(19)}$, tentou-se o modelo secularista «à ocidental» em muitos dos países islâmicos. A Turquia de Attaturk, o Egipto de Nasser e Sadat, a Síria, o Iraque, a Pérsia e mesmo os primeiros tempos do Paquistão, em 1947, introduziram regimes secularistas, mas, de uma forma ou de outra, os modelos foram-se perdendo e, com um grau menor ou maior, a Sharia voltou a

(16) «ARevolução Científica deu origem às religiões humanistas, nas quais os deuses foram substituídos pelo homem [...] os humanistas adoram o homem [...] a ideia base de religiões humanistas como o liberalismo, o comunismo e o nazismo é a de que a essência única e sagrada do Homo Sapiens é a fonte de todo o sentido e autoridade no universo» (Harari, 2017:n 116).

(17) «Secularismo - um regime que não procura coagir a conformidade religiosa» (Owen 2016: 305); acrescenta Yusuf al-Qaradwi: «Secularismo é compatível com o conceito ocidental de Deus, que afirma que, após Deus ter criado o mundo, Ele deixou-o para depois o observar» (Fernandes, 2017: 158).

(18) «As leis do Knesset devem também receber a bênção do Grande Rabinato» (Neves 2012: 174).

(19) «Durante quase toda a sua história, o império mostrou ao mundo um modelo político eficaz de um sistema político multirreligioso» (Quataert 2015: 26 e 28). 
impor-se como referência auxiliar, substitutiva, ou mesmo absoluta, em muitos destes países. O Islão político é um modelo em vigor. O que une uma parte dos muçulmanos no mundo inteiro, para além da religião, é a pertença a um sistema político que se manifesta de múltiplas formas e processos, mas que tem um fim comum: a adoção de uma determinada forma de Sharia, porque há múltiplas interpretações da mesma, que pode ser assumida, de modo direto, indireto, adaptado ou total. «Os islamitas discordam profundamente entre si sobre o conteúdo da Sharia, o papel do clero na sua interpretação, sobre qual será a versão correta» (Owen 2016: 37). Muitos muçulmanos perseguem este desiderato através da legalidade e sem recorrer à violência ${ }^{(20)}$. Esta união em torno de um Islão político, na forma como este se assumir, transcender ou evoluir (Owen 2016: 193-195), marcará seguramente uma parte da filosofia política global nas próximas décadas.

Este também não é apenas um assunto de hoje, mas sim intemporal; já Thomas More lhe dedicou uma parte significativa da sua Utopia (1516), procurando criar uma ideia de que, independentemente da religião predominante num determinado Estado (More referia-se ao Cristianismo em geral), a tolerância, a inclusividade e o respeito absoluto por crenças distintas deviam configurar uma marco incontornável na sua constituição:

que ninguém seja censurado pela religião que professa; [...] cada homem podia seguir a religião que quisesse, e poderia fazer todo o possível para conquistar a adesão dos outros, com a condição de o fazer calmamente, com sobriedade e doçura, sem invectivas e desprezo por eles (More 1516: 126).

Este direito outorgado de poder defender a sua própria religião, desde que o fizesse «calmamente, com sobriedade e doçura», é assumido como um direito de cada um de professar a sua crença, e também de lhe ser permitido tentar convencer os outros da sua fé, mas sempre dentro da norma social, do respeito e da tolerância, porque seria «absurdo e

(20) «Há provas abundantes de que, pelo menos no Médio Oriente, o muçulmano médio é agora de tendência islamita. Maiorias significativas em países como a Jordânia, o Egipto e o Paquistão querem que as suas leis derivem do Alcorão e do Hádice» (Owen 2016: 30). 
presunçoso obrigar outro a adotar a mesma crença pela violência ou ameaças» (More 1516: 127).

\section{Da guerra, da paz e de Deus}

A guerra, tão antiga como a própria história da Humanidade, nasce e alimenta-se das divisões e vence-se, fundamentalmente, pelo poder da união, embora também, como afirmam os postulados de Maquiavel, usando muitas das vezes o que divide uns de outros em proveito de uma aliança conjuntural (Maquiavel, 1532: 28-29). As guerras opõem grupos de seres humanos, opõem nações, Estados e uniões de países. A expressão guerra também pode ser usada para o conflito entre Homem e Deus, entre os Anjos e os Demónios, em suma, entre o «Bem» e o «Mal». A simplificação absoluta quase nunca existiu; se fosse assim tão simples definir que de um lado está o «bem» e do outro o «mal», a guerra teria a sua justificação universalmente aceite... Mas, quase sempre, o que se afirma na defesa do «bem» é acusado de ser o «mal» pelo respetivo adversário. «A facilidade para fazer a guerra, unida à tendência dos detentores do poder que parece ser congénita à natureza humana é, pois, um grande obstáculo para a paz perpétua» (Kant 1795: 133).

Mesmo tomando apenas por base as chamadas «religiões do livro», vemos como foi recorrente a invocação divina para ajudar, para tomar partido e para interferir diretamente nas batalhas entre os homens. Mesmo nos textos sagrados, esta questão aparece. Por exemplo, lemos no Antigo Testamento que Moisés pediu ajuda a Deus contra os Amalecitas (Êxodo, 17.8-16); quando levantava os braços em direção a Deus, Josué ganhava e, quando os baixava, perdia, até que os Amalecitas foram derrotados. Maomé também recebeu ajuda durante a batalha de Badr, em 624 (Alcorão, 3.19 e 8.9, 19 e 65), incluindo a ajuda de anjos para derrotar os Coraixitas de Meca. Se o texto sagrado reflete a interferência divina nas contendas entre homens, então é natural que os mesmos tentem o seu apoio nos principais conflitos, justifiquem as suas ações com argumentos religiosos e, inclusivamente, procedam, após as batalhas, de acordo com o que o «divino» ordenou.

Se perdermos de vista o contexto histórico dos textos sagrados, a época e o significado que então tinham, se não fizermos uma exegese positiva para entendermos o significado e o que se pretende dizer, cairemos no literalismo cego: «A violência e a intolerância vêm da leitura 
integral, fundamentalista e imutável, da palavra esclerosada [...]. O fundamentalismo é a transformação da religião em ideologia» (Mucznik 2012: 42-43).

Levar à letra, sem contexto, sem explicação, sem acrescentar a leitura abrangente de todo um texto, sem um caminho de explicação, é ficarmos reféns das mensagens que tudo podem justificar. Encontramos textos possíveis destas interpretações, tanto na Bíblia como no Alcorão. Por exemplo, no Livro dos Números (Antigo Testamento), um texto que é base comum a judeus, a cristãos e a muçulmanos, lemos uma passagem que, se não for contextualizada, é profundamente violenta; devidamente manipulada, até poderá servir para justificar inúmeras ações:

Guerra contra Madiã [hoje Arábia Saudita] - Iahweh falou com Moisés e disse: Vinga os israelitas nos madianitas [...] Fizeram a guerra contra Madiã, conforme Iahweh ordenara a Moisés, e mataram todos os varões [...] levaram cativas as mulheres dos madianitas com as suas crianças, e tomaram todo o seu gado [...] queimaram as cidades [...] Moisés indignou-se contra os comandantes: «Por que deixaste com vida todas essas mulheres? [...] Matai, portanto, todas as crianças do sexo masculino. Matai também todas as mulheres que conheceram varão, coabitando com ele. Não conserveis com vida senão as meninas que ainda não coabitaram com homens e elas serão vossas» (Números 31, 1-18).

Moisés, de acordo com Carreira das Neves (fazendo a necessária exegese), mostra que o profeta é «um herói a seguir e não ser seguido», um homem que matou, que errou, que acabou por não chegar à Terra Prometida «por Castigo Divino» (Neves 2012: 154), ou seja, que demonstra a imperfeição humana, as ações tomadas e as justificações apontadas, porque tudo tem um contexto profundamente humano, histórico e circunstancial. Os textos existem para que possamos pensar, questionar e afirmar caminhos de futuro e nunca, porque essa não é seguramente a intenção, para buscar em contextos completamente ultrapassados justificações para irracionalidades atuais ${ }^{(21)}$.

(21) «São palavras de Deus em palavras humanas. Quer os seus autores quer os seus leitores escreveram e leem com uma pré-compreensão, isto é, no quadro de pressupostos históricos e culturais, interesses e expetativas. Portanto a sua leitura nunca pode ser literal, pois implica sempre uma interpretação» (Borges 2012: 11). 


\section{Guerra Justa, Guerra Santa e Jihad}

Sabe-se da importância dos conceitos religiosos para o que se denominou de guerra justa, de guerra santa ou de Jihad $^{(22)}$. Ou seja, mesmo antes de uma guerra ou conflito, procuram-se justificações para a fazer ${ }^{(23)}$. Pela defesa das populações a causa é quase sempre justa, mas, quando se ataca «em nome de Deus», torna-se muito mais difícil e ambígua a sua justificação. As cruzadas são um excelente exemplo, onde a política se confunde com a religião, onde se mistifica a guerra entre religiões e onde se esquece a dimensão geopolítica que enforma a narrativa dos beligerantes.

A hierarquia dos valores torna-se fundamental para entender as razões invocadas. Para um budista, as escrituras têm menos importância do que a experiência do Homem e do que a razão; mas, para um muçulmano, a palavra de Deus revelada no Alcorão tem precedência sobre tudo, pelo que, sem entender a base valorativa de quem argumenta, não se conseguem racionalizar as causas evocadas e os efeitos pretendidos. A Igreja Católica, no seu Catecismo - numa evolução do pensamento de Santo Agostinho e de São Tomás de Aquino que se manteve até ao século $X X^{(24)}$-, o qual foi promulgado pelo papa João Paulo II a 15 de agosto de 1997, refere (n. . 2309): «Devem ser ponderadas com rigor as estritas condições de uma legítima defesa pela força das armas (prefere-se a expressão "evitar a guerra" a "fazer guerra")».

(22) Entendida, neste contexto, como Jihad Maior: «um apelo à defesa bélica do Islão»; «vulgarmente entendido como guerra santa»; «o combate armado só deve ser levado a cabo para vencer as forças do mal», porque também se aplica o termo à Jihad Menor: «empenhamento, esforço, luta; combate espiritual ou físico contra o demónio»; «respeito ao exercício da divulgação da ideologia islâmica» (Quevedo 2017: 94, Ahmed 2002: 288; e Siddiqui 2015: 171-172).

(23) "Os cruzados cristãos, de Pierre Dubois, na França medieval, a Stonewall Jackson, nos Estados Confederados da América, invocaram a Bíblia e os ensinamentos cristãos para justificar a guerra santa» (Owen 2016: 50).

(24) «As três condições da guerra justa (bellum iustum) são, portanto, a autoridade legítima (legitimas auctoritas), a causa justa (iusta causa), como a legítima defesa perante um ataque, e a reta intenção (recta intentio) de promover o bem e evitar o mal. Alguns teólogos posteriores, como o dominicano Francisco de Vitória (1483-1546) e o Jesuíta Francisco Suárez (1548-1617) [...] juntaram mais duas condições: [...] a guerra como último recurso (ultima ratio), e que a forma fosse proporcionada ao fim, atuando sempre da maneira mais justa (minus-malus), sem nunca sacrificar inocentes» (Neves 2006: 206). 
A religião pode servir-se da guerra para afirmar uma ideia, uma mensagem, uma forma alternativa de vida que a previna, que a evite ou mesmo que a justifique ${ }^{(25)}$. A guerra, a política de um povo, de um líder, de uma nação, podem ser objeto de argumentação por parte da religião e aqui se podem encontrar fundamentos para fazer a guerra; porém, nunca conseguirá, exclusivamente, justificá-la. Mesmo em casos onde parece que a guerra é causada pela religião, rapidamente encontramos outras «guerras» dentro dessa, entre as nações, entre os interesses geopolíticos, entre modelos políticos, entre secularistas e religiosos e entre os vários apoios internacionais que cada parte recebe. A guerra pode ser, também, produto da religião, mas nem as religiões nascem em virtude das guerras, nem as religiões são causa única das guerras!

A paz constrói-se no respeito pelo tempo, pelo contexto e pelo investimento num futuro o mais estável possível. No caso das religiões, não se podem evocar razões «da palavra» se não se entender e fizer uma leitura correta do contexto em que estas aparecem ${ }^{(26)}$. Além do enquadramento histórico e geopolítico, há um outro também muito importante, que deriva do «género literário», da forma escolhida para o escrever, para o traduzir, ou para o adaptar:

O literalismo da Bíblia, para judeus, católicos, protestantes e evangélicos, só conduz ao fundamentalismo bíblico. Há que ler o texto no seu contexto e sempre de acordo com os géneros literários [...] Não foi a Bíblia que construiu a «Comunidade», mas a «Comunidade» que produziu a Bíblia (Neves 2012: 170).

\section{A busca da Paz}

O desejável é que a paz seja produto da vontade dos povos em disputa, mas, como frequentemente acontece na História, ela é muitas

(25) Como defendeu, de forma assertiva, Martinho Lutero em 1543, no seu célebre prefácio ao Alcorão: «Os papistas defendem a idolatria, os Judeus as monstruosidades dos anabatistas, Servetus e outros. Vamos agora preparar contra Maomé [...] Leiam os escritos do inimigo para o poderem refutar de forma absoluta, para o desmontar em pedaços e os desfazer, com o objetivo de garantir alguma segurança, ou no mínimo, para fortificar as nossas gentes com mais argumentos de estudo» (Heinrich 1996: 266).

(26) «Não é possível entender a Bíblia sem a Lógica» (Harari 2017: 265). 
das vezes o resultado da subordinação das partes a uma força maior. A paz, na maioria das vezes, resulta de um compromisso para terminar a guerra e não de um cometimento ou de um compromisso futuro para a conservar: «no momento, nenhuma das partes faz menção porque ambas estão demasiado esgotadas para prosseguir a guerra» (Kant 1795: 130). Judeus e Assírios viveram períodos de paz quando eram parte das satrapias (províncias administrativas) persas; os Judeus também acalmaram nas suas disputas com o Império Romano no início da era cristã. Por vezes, a paz é também o resultado da existência de um inimigo comum: povos desavindos que se juntam contra um terceiro e que criam alianças defensivas que se podem tornar perenes e instituídas. Um caso paradigmático foi a união entre os povos ibéricos, Portugal e Espanha, para expulsar o invasor francês entre os anos de 1808 a 1814, o que, de uma forma muito significativa, marcou uma nova época de paz entre povos que, até hoje, não mais se confrontaram em guerra aberta (a Guerra das Laranjas, em 1801, e a invasão franco-espanhola de 1807 foram as últimas confrontações abertas entre os Portugueses e os seus vizinhos). A paz é um caminho de aproximações e não deve resultar de imposições.

Vencer absolutamente pode significar a destruição material do adversário e a reprovação dos valores defendidos pelo vencido; todavia, desse modo, não é a paz que se obtém, mas simplesmente a supremacia de um dos beligerantes sobre o outro. «Deus não está com os exércitos mais poderosos, mas com aqueles que melhor atiram» (Voltaire 1759: 17). A paz, na sua essência, pode ser obtida desejavelmente sem confronto violento mas, em qualquer caso, para que seja duradoura, deve tentar ser o mais consensual e aceite por ambas as partes. Isto não se consegue com claras vitórias ou derrotas, mas antes pelo encontro dos fins perseguidos. A paz, em política ou no domínio religioso puro, não pode passar pela simples afirmação e imposição de um sistema sobre outro. Se um determinado sistema político é apelativo e é considerado justo e eficaz, então não será necessário impô-lo. No princípio mais puro do Direito Internacional, a cada povo, a cada nação, deve ser dada a oportunidade de escolher o seu modelo político e de garantir a respetiva liberdade religiosa ${ }^{(27)}$; no entanto, há muitas maneiras diferentes

(27) Como podemos observar, por exemplo, nosEUA, onde a maioria dos muçulmanos defende mudanças e uma evolução na prática da sua religião: «U.S. Muslims are religiously observant, but 
de o fazer. Um Estado pode afirmar-se como secular e tentar suprimir as religiões (secularismo negativo), ou pode antes separar as atividades da esfera estatal das da esfera religiosa e aceitar elementos conceptuais desta última - secularismo positivo (Owen 2016: 264-272). Pode também buscar um modelo híbrido que adote práticas seculares e religiosas, ou, finalmente, instituir um modelo assente numa determinada orientação religiosa, em menor ou maior grau, como sabemos acontecer em muitos dos Estados atuais. A questão reside, pois, em saber o que é aceitável pelos próprios cidadãos de cada Estado, e aquilo que não fere os princípios universais da esmagadora maioria das populações.

Parece relativamente consensual afirmar que, desde que um cidadão se considere abrangido pela proclamada Declaração Universal dos Direitos Humanos, o sistema em que se insere deverá ter as condições mínimas para o garantir ${ }^{(28)}$. Se for uma democracia constitucional ${ }^{(29)}$, isso quererá dizer, em princípio, que há limites impostos aos que governam e que estes têm de prestar contas às populações que os elegeram para governar. O sistema político escolhido, desde que não seja imposto e desde que responda a alguns requisitos básicos, como os que estão expressos na Declaração acima referida, será sempre um sistema em evolução, no qual os cidadãos que nele vivem encontrarão formas de o saber aperfeiçoar e de o servir melhor:

Toda a pessoa tem direito à liberdade de pensamento, de consciência e de religião; este direito implica a liberdade de mudar de religião ou de convicção, assim como a liberdade de manifestar a religião ou convicção, sozinho ou em comum, tanto em público como em privado, pelo ensino,

open to multiple interpretations of Islam» (http: / / www.pewresearch.org/fact-tank/2017/ 08/28 / u-s-muslims-are-religiously-observant-but-open-to-multiple-interpretations-of-islam/ - consultado em 16 de Setembro de 2017).

(28) Importa notar que houve um grupo de países muçulmanos que considerou esta Declaração Universal dos Direitos Humanos, das Nações Unidas, como inaceitável. Fez, por isso, uma nova declaração do Direitos Humanos (no Cairo, em 1990), considerando que os direitos humanos são os definidos pela Sharia, baseada no Alcorão e nos Hádices, com um grande número de preceitos morais que variam entre países, não existindo, como vimos, uma Sharia única aceite por todos (http: / / opiniaopublica.ufmg.br/emdebate/ Artigo_mohammad_portugues.pdf, consultado em 18 de setembro de 2017).

(29) «A Declaração Universal dos Direitos Humanos [... . é talvez o que mais se aproxima de uma constituição global» (Harari 2017: 32). 
pela prática, pelo culto e pelos ritos. (Artigo 18 da Declaração Universal dos Direitos Humanos).

\section{Os soldados, os exércitos e a paz}

A Paz também é obra de soldados que, inseridos em Forças Armadas institucionais e desenvolvidas (como são, por exemplo, as que constituem os países da União Europeia), são, em si mesmos, o garante da sua preservação e defesa. Os soldados e as instituições militares inseridas em sociedades democráticas e evoluídas merecem-nos, por isso, algumas linhas de reflexão, pelo seu contributo maior para a busca e para a afirmação da paz mundial.

Os soldados que no campo de batalha matam e morrem, porque acreditam na causa superior que os levou ali, sabem entregar o seu bem mais precioso, a vida, na esperança de obter a paz. Combatem, quase sempre (embora nem sempre, porque também há os que combatem pelo dinheiro, pela violência ou pelo ódio), na crença de que apareça alguém, humano ou divino, que ponha fim à disputa, à violência, e que lhes dê uma via nova para uma paz o mais duradoura possível, ao mesmo tempo que sonham, como tantos o fazem e fizeram, com uma «paz perpétua»(30). O soldado está na linha de frente, na defesa dos seus irmãos, na entrega pela vida e na valoração da fé em algo maior. No entanto, a natureza humana não garante que os valores que se defendem sejam efetivamente aqueles que guiam a conduta dos soldados. São os exércitos, as Forças Armadas, em países estáveis e desenvolvidos, que garantem que a violência só é exercida de facto quando mais nada se pode fazer, dentro da ordem e da legalidade e sempre na busca do restabelecimento da paz.

Quando atua, o Exército, se desencadeia o seu formidável poder destruidor, não é a destruição que visa. Não quer exercer uma represália. Não quer afirmar uma explosão de orgulho. Quer simplesmente salvar um direito ameaçado, e por isso recorre à violência, que é forçado a utilizar, não todavia por amor à violência, mas tão-somente do direito que sem ela não poderia defender-se [...] O Exército é a melhor segurança da paz

(30) Do livro e obra de Immanuel Kant: A Paz Perpétua e Outros Opúsculos (ver bibliografia). 
e, por esse motivo, uma das mais eficazes salvaguardas da civilização (Rodrigues 1959: 10).

Além disso, há um papel profundamente unificador na sociabilização que se vive nas Forças Armadas, porque são uma instituição inclusiva, onde não se distinguem etnias, religiões, estatutos económicos ou discriminações de género. Estão pensadas e foram alicerçadas no respeito pela função/posto e na progressão assente em critérios de mérito. Além de serem um garante da utilização, profundamente cuidadosa, da força também são um exemplo de integração e compreensão entre todos os que, envergando o mesmo uniforme, se respeitam como iguais, independentemente das múltiplas origens, servindo valores e ideais comuns ${ }^{(31)}$.

\section{Uma reflexão final}

A História da humanidade dá-nos inúmeros exemplos em que a tolerância e a inclusão se sobrepuseram à violência e à imposição de vontades políticas, ideológicas e religiosas. No entanto, mesmo quando a abertura foi grande, havia como que um gesto de magnanimidade, embora pudesse ser de puro interesse económico, entre os que detinham o poder, a religião ou a ideologia dominante sobre aqueles que queriam preservar a diferença. Os outros, os que se submetiam, podiam manter a religião e a tradição, desde que pagassem um imposto ou cumprissem determinadas obrigações sociais, discriminadas e diminuídas, de uma completa cidadania. Os Omíadas na Península Ibérica permitiam os ritos aos cristãos, como D. Afonso Henriques permitiu as mourarias e as mesquitas aos muçulmanos e as judiarias e as sinagogas aos judeus (Mattoso 2012). Mas, da mesma forma que houve tolerância de um sobre o outro (embora um estivesse, como vimos, no controlo do poder e concedesse apenas parte dos direitos ao outro), também houve alterações bruscas através de mudanças de poder, de circunstância ou de momento geopolítico. Os que antes eram tolerados foram então expulsos, forçados

(31) Por exemplo, sobre os Estados Unidos da América, afirmou o antigo Secretário da Defesa, Leon Panetta (2014: 364): «The military is a great American equalizer. It takes men and women from all parts of the country, from all ethnic and religious backgrounds and economic strata, and joins them in common purpose». 
à conversão ou cerceados, na sua plenitude ou pelo menos em grande parte, dos respetivos direitos.

Para haver paz e não guerra não poderá haver, entre os principais poderes mundiais, uns que tenham uma visão que se sobreponha à de outros. Embora seja positiva a tolerância, esta não chegará para garantir um sistema de respeito, de igualdade entre credos, de respeito absoluto entre convicções. Tem de haver um repúdio intransigente a respeito da imposição de valores. Ou seja, «colocar o diálogo no lugar do combate, e, sobretudo, retirar Deus do campo de batalha» (Moreira 2012: 68). O instrumento legal já existe (a Declaração Universal), mas a forma de a garantir, de a aplicar, está muito longe de poder ser uma realidade.

Há um longo caminho evolutivo a percorrer e este deverá valorizar a busca do conhecimento para se entender o papel da Humanidade no extenso universo ${ }^{(32)}$, ou seja, na ciência, na ética, na filosofia, no entendimento entre culturas, entre sistemas políticos, entre ideologias e entre religiões, mesmo que se revelem completamente diferentes daquelas que hoje conhecemos ${ }^{(33)}$.

Podemos ainda não ter uma solução acabada que nos coloque no caminho certo para a "paz perpétua», mas ela passará sempre pela razão e pelo diálogo. Voltar para trás não deveria ser uma opção, mas ela é, efetivamente, uma possibilidade que tem de ser permanentemente acautelada. Temos de estar conscientes e de saber que há caminhos que nos podem possivelmente conduzir a uma sociedade intolerante, fragmentada e, no pior dos casos, radicalizada em crenças, ideologias ou religiões. Temos de saber que, em determinadas regiões do mundo, mesmo que o resto da Humanidade escolha um outro caminho, muitos poderão escolher o caminho do totalitarismo ideológico. A dúvida, a razão e a busca de conhecimento é a garantia para se encontrar um caminho para uma paz mais duradoura e, quem sabe um dia, para uma paz perpétua.

(32) «Temos de viver em Nações que valorizem a busca para entender a papel da humanidade no Universo» (Tyson 2017: 194).

(33) «As novas religiões surgirão dos laboratórios de investigação [...] as novas tecnoreligiões podem ser divididas em dois grupos principais: o tecno-humanismo e a religião dos dados [...] o Dataísmo, uma religião que, em vez de venerar os deuses ou o homem, adora somente os dados» (Harari 2017: 393 e 410). 


\section{Bibliografia:}

Ahmed, Akbar (2002). O Islão. Lisboa: Bertrand.

Bazaglia, Paulo (direção editorial) (2015). Bíblia de Jerusalém. São Paulo: Paulus. Bento XVI, Papa (2006). Discurso Do Santo Padre aos Representantes do Mundo Científico e Cultural da Baviera na Aula Magna da Universidade de Regensburg. Disponível em: http://www.montfort.org.br/bra/veritas/ papa/papa_regensburg/ (consultado em 18 de setembro de 2018).

Borges, Anselmo e Monteiro, João Gouveia (Coord.) (2012). As Três Religiões do Livro. Coimbra: Imprensa da Universidade de Coimbra.

Correia, Carlos João (2012). «Religiões Proféticas e Místicas», in Borges, Anselmo e Monteiro, João Gouveia (Coord.), As Três Religiões do Livro. Coimbra: Imprensa da Universidade de Coimbra, 81-86.

Damásio, António (2017). A Estranha Ordem das Coisas: A Vida, os Sentimentos e as Culturas Humanas, Lisboa: Temas \& Debates.

Djevi, Faisal (2016). "Against Muslim unity», Aeon. Disponível em: https://aeon.co/essays/the-idea-of-unifying-islam-is-a-recent-invention-and-a-bad-one (consultado em 02 de Novembro de 2017).

Fernandes, José Pedro Teixeira (2017). O regresso da Geopolítica: Europa, Médio Oriente e Islão, Lisboa: Almedina.

Flannery, Frances L. (2016), Understanding Apocalyptic Terrorism_Countering the Radical Mindset. Nova Iorque: Routledge.

Harari, Yuval Noah (2017). Homo Deus. Amadora: Elsinore.

Hazleton, Lesley (2015). O Primeiro Muçulmano: A História de Maomé. Amadora: Elsinore.

Heinrich, Sarah e James L. Boyce (1996). «Martin Luther - Translation of two prefaces on Islam: Preface to the Libellus de ritu et moribus Turcorum (1530) and Preface to Bibliander's Edition of the Qur'an (1543)», World \& World, Vol. XVI, Number 2, Spring, St. Paul: 250-266.

Kant, Immanuel (2016 v.o. de 1795). A Paz Perpétua e Outros Opúsculos. Lisboa: Edições 70.

Mamede, Suleiman Valy (Introdução e notas) (1989). Alcorão, (Parte I e II). Mem Martins: Publicações Europa América.

Maquiavel, Nicolo (1991 v.o. de 1532). O Príncipe: A Arte da Guerra. Lisboa: Ediclube.

Mattoso, José (2012). «As três religiões do livro», in Borges, Anselmo e Monteiro, João Gouveia (Coord.), As Três Religiões do Livro, Coimbra: Imprensa da Universidade de Coimbra, 95-100. 
More, Thomas (1995 v.o. de 1516). Utopia, Lisboa: Publicações Europa-América.

Moreira, Adriano (2012). «Estado e Igreja depois do 25 de Abril», in Borges, Anselmo e Monteiro, João Gouveia (Coord.), As Três Religiões do Livro, Coimbra: Imprensa da Universidade de Coimbra, 63-70.

Mucznik, Esther (2012). «O Monoteísmo conduz ao fundamentalismo?», in Borges, Anselmo e Monteiro, João Gouveia (Coord.), As Três Religiões do Livro. Coimbra: Imprensa da Universidade de Coimbra Portugal, 39-45.

Neves, João César das (2006). O Rapto do Santo: www.raptussancti.net. Lisboa: Verbo.

Neves, Carreira das (2012). Deus Existe? Uma viagem pelas religiões. Lisboa: Editorial Presença.

Owen, John M. (2016). O Islão Político: Ontem e Hoje. Lisboa: Bertrand Editora.

ONU (Organização das Nações Unidas) (1948). Declaração Universal dos Direitos do Homem. Disponível em: http://www.gddc.pt/direitos-humanos/textos-internacionais-dh/tidhuniversais/cidh-dudh.html (consultado em 18 de setembro de 2017).

OIC (Organization of the Islamic Conference) (1990). Cairo Declaration of Islamic Human Rights. Disponível em: http://www.fmreview.org/ sites/fmr/files/FMRdownloads/en/FMRpdfs/Human-Rights/cairo. pdf (consultado em 18 de setembro de 2017).

Panetta, Leon (2014). Worthy Fights: A memoir of leadership in War and Peace. Nova Iorque: Penguin Books.

Quataert, Donald (2015). O Império Otomano: Das Origens ao Século XX. Lisboa: Edições 70.

Quevedo, Carlos (2017). E Deus criou o mundo. Lisboa: Desassossego.

Rodrigues, António dos Reis (1959). Apologia do Exército. Separata da Revista de Infantaria n. ${ }^{\text {os }}$ 155-156 Novembro Dezembro, Lisboa: Academia Militar.

Siddiqui, Abdur Rashid (2015). 100 minutos com o Alcorão. Lisboa: Sinais de Fogo.

Tyson, Neil de Grasse (2017). Astrophysics for people in a hurry. Nova Iorque: W.W. Northan \& Company.

Voltaire (2017, v.o. de 1759). Cândido ou o Optimismo. Matosinhos: Cardume Editores. 